\title{
EXPLORATION OF EFL TEACHERS' EXPERIENCE TOWARD THE IMPLEMENTATION OF E-LEARNING AMIDST THE COVID-19 PANDEMIC: A QUALITATIVE INTERVIEW STUDY
}

\author{
Lee Khowvtsheva G Karaeng1, Debora Catherin Simanjuntak ${ }^{2}$ \\ 1,2 Universitas Advent Indonesia \\ ${ }^{1}$ gtsemanitakaraeng@gmail.com, ${ }^{2}$ debora.simanjuntak@unai.edu
}

\begin{abstract}
This ongoing pandemic has demanded a rapid response to the unparalleled suspension of face-to-face teaching around the world. There has consequently been a growing interest in finding out how educators cope up with the transition. This study aims to explore the experience that EFL teachers in Jayapura encountered regarding the implementation of e-learning during the COVID-19 Pandemic. The data were collected through semi-structured interviews. A selection of $11 \mathrm{EFL}$ teachers as the informants of this study was made based on the criteria of the study. By synthesizing the relevant literature with the collected data which were analyzed using thematic analysis, the findings were valued and wisely reviewed. The examination results of this study showed there are two emerging themes on teachers' experience in implementing e-learning, the themes are facilitating student learning and outcomes and self-regulated learning. Other themes that appeared were reviewed in terms of challenges, namely, obtaining interactive learning and teaching adjustment during transition. The findings can have important implications for ensuring the effective use of implementing e-learning toward English teaching.
\end{abstract}

Keywords: EFL Teacher, Experience, Implementation, E-learning, COVID-19

\section{INTRODUCTION}

This Covid-19 pandemic has halted some daily activities in various fields, such as the economy, livelihoods and even education. The Government issued a regulation for teachers, students, parents and schools to accept a transition period, from face to face class to online learning. Henceforth the Ministry of Education and Culture has adopted a policy of teaching and learning process to be carried out through e-learning. Taradisa, Nidia., Jarmita, Nida. (2020) emphasized that even though the pandemic has not been over yet, the learning system should remain effective. Educators should inculcate in their students' minds that education should not be ended in spite of the ongoing outbreak. Tanveer (2015) stated that the prospect of e-learning should be introduced with the intention of enabling each student to obtain learning opportunities in a more flexible way. E-learning must be made of the teachers to make it more efficient, attractive and enjoyable. Zhang et al. (2006) defined e-learning as a teaching and learning activity that involves an online process through due to its capability of carrying out learning activities, there could be real arguments for the growth of the field of education. This approach supports new possibilities for teaching and learning in many areas for learning the way this method works unlike conventional classroom settings (Rebaque-rivas and Gil-rodr 2019).

E-learning environments indicated two methodologies of learning that are based on the internet, they are Synchronous and Asynchronous learning. Asynchronous learning offers content 
material that is widely accessible for audio or video lectures, handouts, reports, and presentations of power points for the students (Perveen 2016). On the other hand, synchronous teaching strategies facilitate learning and teaching and provide several opportunities for students and teachers to associate, share, and be willing to collaborate and ask questions through synchronous learning technology in real time (Higley 2013). Both synchronous and asynchronous are used to support learning systems which require technology to conduct teaching and learning processes. These two methodologies provide an active, fun and measurable learning process.

E-learning has become one of the ways out in the world of education nowadays, especially for practicing the terms of school from home (SFH) due to COVID-19. Hasan and Bao (2020) stated Online-classes are considered as a one of the solutions and very crucial needs due to the institutional isolation during the unpredictable time. Through E-learning, students can still take part in lessons without direct contact with teachers and other students and individualizes the learning experience for each student. Though e-learning takes place virtually, teachers have to develop an indestructible relationship between them and the student as in their face to face class. Entering the digital 4.0 era, there have been some advances in several aspects and the education system is among them (Lase 2019). In the field of education, many e-learning applications have been created in order to help students to learn.

As a result study of (Bao 2020) students also experience difficulties when they are isolated at home, such as lack of self-discipline, appropriate instructional resources or a pleasant learning environment. Additionally Dewaele, Magdalena, and Saito (2019) identified the lack of enjoyment in the classroom leaves students feeling discomfort and frustration. To deal with the SFH (School from home) problem, teachers as the facilitator should be responsible for living a vibrant and effective learning environment for the students.

The transition from offline to online learning has given a huge impact on the education system in Indonesia. It is such a new experience for teachers currently in accepting this virtual teaching. All the teaching process is done virtually. Start by delivering online tutorials, incorporating new learning material, providing variation of activities, providing input, and also performing online evaluation König, Jäger-Biela, and Glutsch (2020). In the previous experience, they only used platforms or online learning application media as variations in making the teaching style more exciting and to introduce the use of effective technology in learning to students. But they don't really use all platforms as the main tool in learning. This significant difference also applied for the students. Normally in the face to face class, students were typically expected to listen to their teachers, work independently or in groups, and reproduce information primarily in tests (Lipowsky and Rzejak 2015). Owing to the use of virtual teaching is something that has just been done and considering it happened suddenly, there are lots of obstacles occurred Period and Study (2020) argued in the transition period of SFH, starting from March 2020 to June 2020 there are many barriers faced by stakeholders which also led to a lack of readiness because this SFH happened suddenly. Recent study of Baticulon et al. (2020) identify constraints that found in e-learning in 5 types, they are "technology, personal, family, institutional and community". And based on the research results, only $41 \%$ of students thought they could handle themselves both physically \& mentally to participate in the online study. Since this research focuses on teachers' experience in implementing e-learning amidst the COVID-19, it is substantial to know what things have been experienced by the EFL teacher in Jayapura in implementing e-learning, how they conduct teaching activities and what challenges they have faced while implementing e-learning during the pandemic. 


\section{E-learning}

In accordance with the circular letter issued by the Ministry of Education and Culture, number 15 of 2020 concerning Guidelines for Organizing Learning from Home in an Emergency for the Spread of Coronavirus Disease (COVID-19). Therefore, the whole teaching and learning process is carried out from home or school from home (SFH), this activity certainly involves electronic media to communicate rather than face to face. Baticulon et al. (2020) stated that elearning should be harnessed to develop learners' understanding and knowledge performance. The implementation of e-learning obtains three components: content, technology and lesson plans. These components are the main focus for the teacher to carry out e-learning into the class.

\section{Offline teaching and learning}

Offline teaching and learning are also well known as a traditional training where student and teacher meet face-to-face at school, and interact directly. The traditional teaching methods are normally led by teachers in where students are taught in a conducive way by sitting and listening Tularam and Machisella (2018). Before the COVID-19 pandemic, schools in Indonesia used offline teaching in conducting a whole of teaching and learning process. It is ranging from lower education to higher education. Although some schools or universities already use online learning, the percentage of traditional learning users is more used compared to online teaching in Indonesia. The thing that stands out the most from offline teaching and learning is the student-teacher interaction. Interactions between student and instructor are essential to the growth of students and teachers are known as the centerpiece or inspirational figure (Donnell and Gettinger 2015); (Johnson et al. 2017).

\section{Virtual teaching}

Throughout the period of covid-19 pandemic, the education system in Indonesia implemented a virtual teaching to become the main process in the learning process. Leading to covid-19 disease, virtual teaching today seems to be the strongest need in different countries. Teachers are struggling to introduce virtual teaching around the world, as virtual teaching needs more effort than conventional teaching. The development of virtual teaching goes hand in hand with the advancement of technology. Computer technology has its own effectiveness in presenting information in a visual format that allows language teachers to use multimedia in the classroom and present linguistic and conceptual objects (Mathew 2019). During the current pandemic, this interactive learning paradigm will proceed. It requires the teacher's careful preparation to process online learning. The quality of virtual teaching heavily depends on the behavior of the teacher or in other words teachers' behavior plays a huge role in a virtual teaching (Myers and Halpin 2002) as cited in (de la Rama et al. 2020).

\section{THEORETICAL BASES}

This study is based on three theories: Distance learning, Connectivism and English Language Acquisition. These theories are relevant to explore people's experience and perceptions on online learning, moreover they provide a variety of pedagogical approaches which support this study.

\section{Distance Learning Theory}

The theory of distance learning has gained many researchers' attention amidst Covid-19 outbreak. It is grounded in facts that the learning process is more versatile for teachers and students; wherein they have the freedom of learning at their own pace (Bradley, Johnson, and Dreifuerst 2020). Distance learning also promotes interaction and relationship between students who work alone and students who prefer to do team work (Costa et al. 2020). 


\section{Connectivism Learning Theory}

Some aspects in education have become complex; hence it is vital for teachers to seek professional learning opportunities through learning networks (Oddone, Hughes, and Lupton 2019). Siemens as the proponent introduces the theory of connectivism to integrate principles of harnessing networks into the teaching and learning process (Siemens, 2005). This theory tied connection and technology together to create opportunities of sharing information across the world. It emphasizes that educators should be able to utilize technology as a platform to engage learners with broader aspects (Utecht and Keller 2019).

\section{English Language Acquisition Theory}

Language acquisition plays an important role in language inventories for learners to build their ability to communicate with the target language. There are still many English students who are only able to use English as a subject to graduate. This is because they are not exposed to a common language objective for communication, especially for those who live in rural areas (HALFFTER et al. 2003). In line with that Al Zoubi (2018) teachers should cooperate with the parents in order to increase learners' awareness of the value of learning English by exposing themselves to the daily language.

\section{TRUSTWORTHINESS}

Researchers carry out trustworthiness to ensure the quality and accuracy of the data. Moretti et al. (2011) claimed qualitative analysis is the breadth of data collected, and that such data must be described and coded in a valid and factual format. Researchers collect data in the field until saturation of data collection is reached. This was done to limit the mistakes of the research. Then the researcher made observations with the situation related to the research topic. The way researchers increase observation persistence by reading research journals, and reading various book references related to the findings studied. Finally, the researchers conducted memberchecking techniques through discussion. This technique is one of the techniques for checking the validity of the data. This technique is done by exposing the final results obtained in the form of discussions via WhatsApp chat with respondents who participated in the research. This procedure aims to increase openness, consistency and honesty from researchers.

\section{METHOD}

In this study, a qualitative study is used to recognize the implementation of e-learning amidst the COVID-19 faced by English teachers. Girolami et al. (2000) stated a qualitative study is an approachable method to collect information that is related to social aspects in life. Qualitative interview studies are beneficial for researchers. As they are perfect for exploring what is still unknown, developing new information, and establishing hypotheses. The aim of using this method is to initiate words as data collection for analysis rather than number. The objective of the study is to enable the researcher to provide useful data from the informants.

\section{Research Instrument}

The researcher performed semi-structured interviews to obtain English teachers' experience regarding the implementation of e-learning. The amount of topics and questions was based on the importance of the subjects. The first preliminary version of the interview was drafted containing a set of topics and questions, adjusting to the estimated maximum time each interview could take. 


\section{Research Participant}

Participants were selected with several criteria such as, participants are EFL teachers who live and work in Jayapura city, they are in the midst of implementing e-learning as an impact of COVID-19, they carry out transition from offline learning to e-learning as a whole process in the teaching activities.

\section{Data Collection}

The data were collected from interviews using a semi-structured interview guide. Semistructured interviews are used when the research would benefit from a fairly open framework. This method is most often used where it is possible to collect more meaningful results from concentrated and conversational two-way dialogue with the respondents (Pathak and Intratat 2012). This method is used to identify respondent's experience about the implementation of elearning amidst the time of COVID-19. The interview was conducted in English in order to create depth conversation with the respondent, so the respondents will be able to answer the question professionally. The researcher approached all the informants through an online interview where they were asked fifteen questions related to their experience in implementing the e-learning into the teaching and learning process during COVID-19 Pandemic. Interviews were conducted through Whatsapp calls that last for about 1 hour per participant. The amount of time chosen seemed adequate, as it would allow the researchers and the informant to become comfortable with each other and obtain the requisite information. Interview was conducted from October 18, 2020 to December 2, 2020.

\section{Data Analysis}

After each interview, the researcher made the transcription and created an initial code then analyzed it by using thematic analysis. Descriptive coding is rated as a suitable source for data forms such as interviews, journals, transcripts and many more. It required the researcher to elaborate the terms of how to deal with differences in data formation and how to code the data (Edition n.d.). The researcher analyzed the data then made a categorization from the initial code so the code would become more efficient.

\section{RESULTS AND DISCUSSION}

\section{Results}

Tabel 1

The table shows the characteristic of the participants $(\mathrm{n}=11)$

\begin{tabular}{ll}
\hline Characteristics & \\
\hline Age & $22-55$ years old \\
Gender & 2 \\
$\square$ Male & 9 \\
$\square$ Female & \\
Educational Status & 10 \\
$\square$ Bachelor's & 1 \\
$\square$ Master's & EFL Teachers \\
Position & 6 \\
E-learning Type & 4 \\
$\square$ Synchronous & \\
$\square$ asynchronous & \\
School & 7 \\
$\square$ Public & 4 \\
$\square$ Privatel & \\
\hline
\end{tabular}




\section{Tabel 2}

Table showing questions, relevant codes and emerging sub-themes pertaining teachers' experience in implementing elearning

\begin{tabular}{|c|c|c|}
\hline Questions & Codes & Sub-themes \\
\hline $\begin{array}{l}\text { How do you deal about the part of } \\
\text { moving your teaching activity from } \\
\text { face to face class to e-learning } \\
\text { class? }\end{array}$ & $\begin{array}{l}\text { - } \text { Supporting device } \\
\text { - } \text { Online-class difficulties } \\
\text { chemistry } \\
\text { - } \text { Teacher-student } \\
\text { communication } \\
\text { - Already knew how to } \\
\text { operate the platform } \\
\text { - } \text { Quite easy in moving } \\
\text { teaching activity to e- } \\
\text { learning } \\
\text { unstable signal } \\
\text { - Supply of the student } \\
\text { needs } \\
\text { - Spend extra time to learn } \\
\text { student's behavior or } \\
\text { willingness } \\
\text { Step that should fix } \\
\text { during the virtual } \\
\text { teaching } \\
\text { Already have experience } \\
\text { with online-class } \\
\text { Get reference and advice } \\
\text { from lecturer }\end{array}$ & $\begin{array}{l}\text { - Teaching and learning } \\
\text { process } \\
\text { - Web-based platform as } \\
\text { learners' preferences } \\
\text { - Corrective E- feedback } \\
\text { - Teaching instructional design } \\
\text { - Teaching Development }\end{array}$ \\
\hline $\begin{array}{l}\text { What is the difference in } \\
\text { implementing the syllabus } \\
\text { between synchronous } \\
\text { asynchronous and normal class? }\end{array}$ & $\begin{array}{ll}\text { - } & \text { Monotone Syllabus } \\
\text { - } & \text { Full syllabus } \\
\text { - } & \text { Full materials in one } \\
\text { meeting } \\
\text { - } \\
\text { - } \\
\text { Unly have short time } \\
\text { - } & \text { syllabus } \\
\text { - } & \text { Time Limitation } \\
& \text { Adjust the time }\end{array}$ & \\
\hline $\begin{array}{l}\text { How do you grade your student's } \\
\text { assignment/tasks? }\end{array}$ & $\begin{array}{ll}\text { - } & \text { Different task for each } \\
& \text { level } \\
\text { - } & \text { Whatsapp group } \\
\text { - } & \text { Send privately through } \\
\text { - Whatsapp } \\
\text { - Google classroom } \\
\text { - Google classroom and } \\
\text { - } \text { Mhatsapp } \\
\text { - } \text { group } \\
\text { - } \text { Submit through } \\
\text { - google drive } \\
\text { - lowered the expectation } \\
\text { - Revised the KKM lower } \\
\text { than before }\end{array}$ & \\
\hline
\end{tabular}




\section{Throughout the process of teaching, how do you elaborate the syllabus to become easy and understandable to your students according to virtual teaching?}

- Explaining Material

- Check student understanding

- Difficult to understand English

- Make it everything very simple

- Choice of words

- Make a translation

- Using Pictures and real items

- less paragraph or words

- Using COVID-19 syllabus

- Achieve the learning target

- Provide video lessons

- Give picture for the example
How do you provide e-feedback to your students?
- Ask them to watch a video

- Answer the question that given

- Submit it through whatsapp

- Comment their work

- Give appreciations

- Give motivations

- Send "good job, well done" sticker to motivate them

- encourage those who haven't submit the assignment

What are your ways to motivate your students to enhance their vocabulary knowledge?
- Listen to English song

- English Youtube Video

- Building step by step

- Letting them know

- Help them to spell the word

- Create sentence by using the word

- A short test

- Make a translation

- Make vocabulary book

- Make vocabulary game

- Watch English youtube video

- Reading articles

- Keep learning

- Personal development

- Study by self

- Join personal development for teachers 


\begin{tabular}{|c|c|}
\hline & $\begin{array}{l}\text { Gather and discuss with } \\
\text { fellow teacher } \\
\text { - Joined educational } \\
\text { webinars } \\
\text { - Ask fellow teachers } \\
\text { - Watch recommended } \\
\text { video from youtube } \\
\text { - Read some resources } \\
\text { from google } \\
\text { - Join the webinar }\end{array}$ \\
\hline $\begin{array}{l}\text { How to carry out the demands of } \\
\text { the syllabus in virtual teaching? }\end{array}$ & 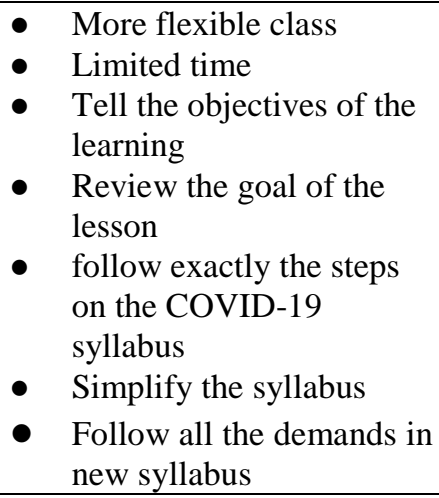 \\
\hline $\begin{array}{l}\text { One of the effective ways of } \\
\text { learning is by group discussions, } \\
\text { How do you overcome this group } \\
\text { discussion during virtual teaching? }\end{array}$ & $\begin{array}{ll}\text { - } & \text { Divide in pairs } \\
\text { - } & \text { Prepare and practice with } \\
\text { - } & \text { Through Google meet } \\
\text { - } & \text { create another meeting } \\
\text { - } & \text { Separate into several } \\
\text { group } \\
\text { - Students will enter each } \\
\text { group } \\
\text { - Join each group to } \\
\text { - } \text { Cosserve } \\
\text { - } \text { classroome back to main } \\
\text { - } \text { Present their discussion } \\
\text { - Create a study group. } \\
\text { - } \text { making video } \\
\text { conversations }\end{array}$ \\
\hline
\end{tabular}

\section{Tabel 3}

Table showing questions, relevant codes and emerging sub-themes pertaining teachers' obstacles in implementing e-learning

\begin{tabular}{|c|c|c|}
\hline Questions & Codes & Sub-themes \\
\hline $\begin{array}{l}\text { What has been the biggest } \\
\text { challenge in applying e-learning to } \\
\text { both synchronous and } \\
\text { asynchronous e-learning? }\end{array}$ & $\begin{array}{l}\text { - Study Hours } \\
\text { - Network Connection } \\
\text { - Teach the student to use } \\
\text { - } \text { Ine platform } \\
\text { - Can't able to catch the } \\
\text { - Student } \\
\text { - Student's comprehension } \\
\text { - } \text { Lack of student's } \\
\text { - Lrab student attention } \\
\text { Low income-family }\end{array}$ & $\begin{array}{l}\text { - Online learning challenges } \\
\text { - } \quad \text { Teacher's instructional design } \\
\text { - } \quad \text { Medium of instruction }\end{array}$ \\
\hline
\end{tabular}




\begin{tabular}{|c|c|c|}
\hline & $\begin{array}{l}\text { Don't have device to Join } \\
\text { class } \\
\text { - Bad connection }\end{array}$ & \\
\hline $\begin{array}{l}\text { How do you elaborate the topic to } \\
\text { your students by using English } \\
\text { through E-learning? }\end{array}$ & 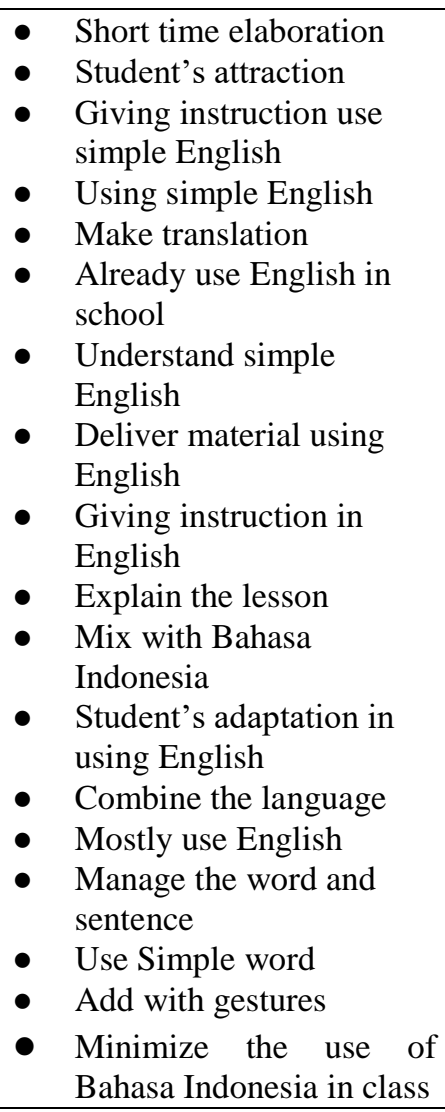 & \\
\hline $\begin{array}{l}\text { Through E-learning, how do you } \\
\text { monitor your student's attitude in } \\
\text { taking English exams/Quiz? }\end{array}$ & 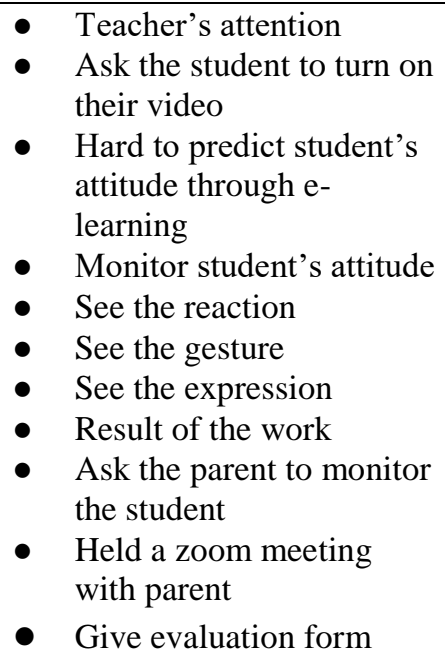 & \\
\hline $\begin{array}{l}\text { How do you teach your students to } \\
\text { operate the learning media } \\
\text { applications? Are they learning by }\end{array}$ & $\begin{array}{ll} & \text { No significant } \\
\text { introduction }\end{array}$ & \\
\hline
\end{tabular}




\begin{tabular}{|c|c|c|}
\hline $\begin{array}{l}\text { themselves or is there an } \\
\text { introduction you did? }\end{array}$ & $\begin{array}{l}\text { - } \begin{array}{l}\text { Students' prior } \\
\text { knowledge }\end{array} \\
\text { - } \text { Provide tutorial videos } \\
\text { - } \text { A week introduction from } \\
\text { school } \\
\text { - Steps how to operate the } \\
\text { platforms } \\
\text { - School gives introduction } \\
\text { - } \text { Practice it at the time } \\
\text { - } \text { Come to school and learn } \\
\text { how to operate it. } \\
\text { - Independent self-learning }\end{array}$ & \\
\hline $\begin{array}{l}\text { What are the difficulties that you } \\
\text { found while using a teaching } \\
\text { application? }\end{array}$ & $\begin{array}{l}\text { poor internet connection } \\
\text { - } \quad \begin{array}{l}\text { Limitation time from } \\
\text { teaching application }\end{array} \\
\text { - } \quad \text { Couldn't able to know } \\
\text { their personality } \\
\text { - Have no significance } \\
\text { difficulties } \\
\text { - Have known those } \\
\text { platforms since in college }\end{array}$ & \\
\hline $\begin{array}{l}\text { What things are you still } \\
\text { struggling with in implementing } \\
\text { the syllabus in synchronous and } \\
\text { asynchronous teaching? }\end{array}$ & 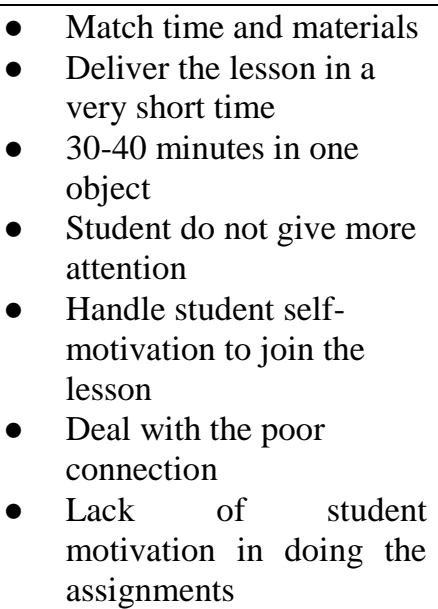 & \\
\hline
\end{tabular}

\section{Findings}

Data saturation was achieved after 10 interviews and no information emerged.

\section{Teachers' Perspectives}

The researchers then composed participants' perspectives into two emerging themes:

\subsection{Facilitate Student Learning and Outcomes}

During the period time of COVID-19 Pandemic, EFL teachers strive the preeminent effort to become a facilitator in order to provide appropriate learning media in delivering material and assisting learners to reach objective learning. In the learning process, teachers basically should have competence to make strategies to facilitate e-learning by utilizing modules, books, teaching materials from the internet and arranging time allocation. By using a facilitation approach, it will supply a scope both for the students and teachers who may not dislike teaching and learning but instead they will love the process of teaching and learning (Aktepe and Coskun 2014). Respondents said by using e-learning platforms it makes it easier for them in conducting e-learning and monitoring student's progression. Based on 
their experience in the field, the way they facilitate student learning was by presenting tutorial videos that could easily accessed by students via the internet. When they gave the instructional video they took from YouTube, some teachers claimed, it was simpler to absorb by the students and also saved time than they had to demonstrate orally.

\begin{abstract}
"Sometimes I will play videos that contain lessons so during the lesson we will only watch videos from youtube channels because nowadays there are lots of educational channels that can be used in learning". (Teacher 2)
\end{abstract}

"If I couldn't able to give them the assignment because of the time limitation that we have in Zoom, I will ask them to watch a video and they will answer the question that I gave". (Teacher 3)

Beside delivering material to student, giving e-feedback is also important in the teaching and learning process. Afify (2018) stated by offering immediate feedback in e-learning, teachers can bring a lot of experience to the learners and help them develop their cognitive ability, during and after the learning process; the learner requires guidance and direct feedback. In providing e-feedback, teachers use applicable, efficient platform yet still contains three functions in e-feedback, in terms of motivating, educating and appreciating students' performance. Giving e-feedback is a means of e-learning.

"The feedback Is actually through Whatsapp chat so whenever they have submitted their assignment, I will give them feedback such as explaining the parts from the assignment that are still wrong, and giving appreciation for those who submit it on time".

\title{
1.2. Self-regulated Teaching
}

According to Perry, Hutchinson, and Thauberger (2008) definition of self-regulated examine learners to participate metacognitively, motivationally, and strategically in the learning process along with their prosperous academic. They argued that deeper understanding of the cognitive, motivational, and situated characteristics of learning can help teachers design better instruction. They acquire the self-regulated learning (SRL) theory that has been used as the basis for the development of the e-learning module. Since e-learning acquired a teaching platform to deliver material. According to the EFL teacher, the media used in virtual teaching is considered as a medium that can facilitate the learning process along with stimulating students' creative thinking. Platforms in e-learning utilized by EFL teachers are Zoom, Whatsapp, Google meet, google drive, Microsoft teams and Yotube. Several EFL teachers shared this opinion:

"Well, I am using Zoom app since it provides you full features to support elearning, but now I prefer using Ms Teams because it saves more internet quota and is more complete in collecting student's assignments". (Teacher 2)

"We use google. So everything in google starts from gmail, google classroom, google drive, google slides and we use quizizz also. The reason why we choose those items is because the school has been using those apps for almost 2 years so we just continue using it because it is very helpful and it is very easy to use. The students and the teacher are also already familiar with those apps". (Teacher 4)

Educational institutions with high standards are those who keep adapting themselves to the changes that occur around them. It is not an easy thing to adapt to new circumstances and new 
systems. Therefore, many teachers prepare themselves by studying independently to adapt themselves to circumstances. Some teachers believed, just like students, teachers also need to evaluate parts that are incomplete and develop their skills. Many teachers believe, in conducting a learning they should have the ability to perform different teaching assignments with a specified quality standard in a particular context (Dellinger et al. 2008). Self-development is carried out both individually or in groups aimed to assess themselves, share experiences in the field amongst colleagues to improve performance, to recognize good learning media for learners, and to increase students' motivation events in virtual teaching. All these things are achieved optimally in series by teachers to become professional and to facilitate e-learning.

"This is actually what I've been doing so I have personal development where I study by myself about the lesson or what apps or platforms that I can use for my student to understand the lesson better without consuming too much data or too much time. Besides, the school already provides the teachers with personal development". (Teacher 3)

A few others said it is important to engage in webinars in order to develop skills and quality. In the era of online teaching and learning, particularly e-learning, technology plays an enormous role. It is a wise way certainly with using current technologies to gain knowledge. Why should webinars be taken up by teachers? According to Webinars are online tools used by instructors in delivering training and education. It can be followed by participants remotely (Gegenfurtner, Zitt, and Ebner 2019). The physical activities undertaken by individuals are very restricted during the pandemic. If teachers usually attend seminars that include information related to the teaching and learning activities, during virtual teaching teachers explore themselves by following webinars in education to acquire knowledge so they can apply it during their teaching. Furthermore, the government is very supportive of the efforts of teachers to strengthen themselves through the manner in which the government works with Pendidikan.id to organize free webinars. And according to the latest phenomenon, the webinar topics used by the experts are relevant and situational.

"I joined many webinars that related to education especially during online learning like for example how to teach in this virtual teaching. I have to think what should I do in this virtual teaching? Because the important thing is how we pay attention to content" (Teacher 3)

"I joined a free educational webinar from the government that I think will help me in order to do virtual teaching”. (Teacher 4)

\section{Teachers' Obstacles}

The researchers then composed participants' obstacles in implementing e-learning into two emerging themes:

\subsection{Obtaining Interactive Learning}

In implementing e-learning, stakeholders face many obstacles. All teachers themselves have been facing their own difficulties. And based on the answers they faced on the field are mostly about how they deal with unstable connections, a very short study hour, deliver the instruction since students have difficulty to understand English, handle students from low-income families and students' willingness in joining class. In online classes, the time changes that happen make teachers have to be innovative between elaborating the topics and presenting material in a short time. This result is similar to the findings of (Period and 
Study 2020), it argues that the allocation of the instructional time that varies in each meeting often impacts the instructional steps, including class attention in the subsequent instruction. Usually in face-to-face class each lesson takes 1 hour in face-to-face class, but during online learning teacher should be shortened learning time to 30-40 minutes due to demand from the government in the curriculum used and also the time constraint of the application or platform used. It is an obstacle felt by teachers because they feel that they are not clear in explaining the material in such a short time, especially often distracted by the network that causes them to continue to enter and exit the application, this hinders them greatly in delivering material to students.

"We only have limited study hours. In the normal class we have 1 hour for one lesson but in the virtual learning we only have 40 minutes based on the COVID19 syllabus and also the time limitation in Zoom aps". (Teacher 1)

"It's quite hard to implement the full syllable in e-learning because we only have short time for online class so we have to shorten everything and we couldn't really achieve the full syllabus because of e-learning class". (Teacher 2)

Another thing that needs to be highlighted in the online learning challenges is the access that facilitates e-learning. The most important thing for teachers before starting online learning is to check the facilities owned by students in order to support them in communicating (Assareh and Hosseini Bidokht 2011). Adequate facilities really support the implementation of e-learning. The teacher argues if students have things that support learning such as the internet, data networks and devices, those things will help them in optimizing the learning process.

\subsection{Teaching Adjustment during Transition}

The ultimate instructional problem shown during the social adjustment or involvement is an important prospect because it determines the progress of students' performance as a whole tertiary education (Ponikarovska 2020). Not just students who experience changes, teachers also undergo these changes. Teachers are expected to react promptly to improvements and to figure out steps they can take to adapt to the situation. The prospect of teaching's adjustment has become the major key in determining teachers in performing their enforcement (Kumar 2015). In short, responding to changes that exist, education leaders should find out a way to immediately design a particular reaction with specific context in opinion while the pandemic settles down (Reimers et al. 2020).

By using teachers' instructional design, teachers can establish their performance. Reigeluth (2013) identified instructional-design theory as a concept that contains instructions about how to actually support individuals learn and grow. In addition, Rozitis (2017) that this instructional design approach could be more beneficial for the online teacher to support their learning activities as they adapt learning objects. These include personality, interchangeable, lower learning units, which can be consolidated into larger content sets. Aside from the role of teachers, schools also contribute to support teachers in supplying student's needs.

"They have been coaching first from the school. The school gives an introduction and they have to practice it at the time. So in the beginning of the semester when we did this introduction, the students came to school with phones to practice”. (Teacher 3 ) 
Although it cannot be denied that there are still many obstacles experienced by students that prevent them from achieving their learning outcomes and mostly it comes from lack of readiness from the teacher. Based on the analysis findings of Churiyah et al. (2020) it could be assumed that there is still a need to assess the adaptation of e-learning in Indonesia throughout the terms of classroom preparation especially in the matter of selecting the proper learning media for the students.

\section{Discussion}

The outspread of the COVID-19 Pandemic has changed the educational system drastically. It is inevitable that teachers, students, and parents are affected by the transition of the education system-form offline to online learning. Through this study, the researchers examined the experience of EFL teachers in conducting e-learning during the time of COVID-19 Pandemic into 2 categories, they are teaching and learning process and self-regulated learning whereas in implementation challenges there are obtaining interactive learning and teaching. adjustment during transition. This underlying factor could be relevant with the transition period that occurred from offline teaching to online teaching and learning. There was a fascinating point found in this study. Based on the most responses given by EFL teachers, the primary interference in delivering content is caused by poor internet connection. As a result, learning becomes very ineffective because they have to go in and out from the system and more often when they leave the system it would be very difficult to log in again. It is in line with the result study of Octaberlina and Muslimin (2020) which stated the lack of internet became a main barrier in implementing e-learning.

\section{CONCLUSION}

The outspread of the COVID-19 Pandemic has changed the educational system drastically. Teachers, students, parents and also schools are affected by the transition of the education system from offline to online learning. The Indonesian government issued requirements for learning to be carried out online or virtual teaching to reduce transmission of the COVID-19 virus. This virtual learning is carried out by utilizing internet technology. In connection with that, cooperation from various parties is needed in implementing e-learning. Moreover, the experience of the teacher in the field is necessary to consider as a reference in implementing elearning better. Based on the analysis of a depth-interview researcher conducted with the EFL teachers shown that there were 4 main finding topics on this research, namely facilitate student learning and outcomes, self-regulated learning, obtaining interactive learning, and teaching adjustment it could be inferred that teacher still need be evaluated in the process of implementing e-learning. In carrying out e-learning into the teaching and learning process, teachers as the spearhead of the educator resources should have the capability to conduct all the elements in e-learning. Teachers are required to help the student in order to customize their experiences as well as fulfill their needs and objectives for personal learning.

\section{ACKNOWLEDGMENTS}

First and foremost, praises to God, the Almighty for His bountiful blessings throughout the process of this research work. We would like to express our deep and sincere gratitude to the research contributors: key informants and school administrators for giving the opportunity to conduct this study and providing insightful thoughts throughout this research. The invaluable guidance throughout this study is a precious thing we could experience. 


\section{REFERENCES}

Afify, Mohammed Kamal. 2018. "The Impact of Interaction between Timing of Feedback Provision in Distance E-Learning and Learning Styles on Achieving Learning Outcomes among Arab Open University Students." Eurasia Journal of Mathematics, Science and Technology Education 14(7):3053-68. doi: 10.29333/ejmste/91619.

Aktepe, Davut, and Lokman Coskun. 2014. "Why Does a Teacher Need to Facilitate the Learning? : A Comparative Study." Journal of Educational and Social Research 4(2):4750. doi: 10.5901/jesr.2014.v4n2p47.

Assareh, A., and M. Hosseini Bidokht. 2011. "Barriers to E-Teaching and E-Learning." Procedia Computer Science 3:791-95. doi: 10.1016/j.procs.2010.12.129.

Bao, Wei. 2020. "COVID - 19 and Online Teaching in Higher Education: A Case Study of Peking University ." Human Behavior and Emerging Technologies 2(2):113-15. doi: 10.1002/hbe2.191.

Baticulon, Ronnie E., Nicole Rose I. Alberto, Maria Beatriz C. Baron, Robert Earl C. Mabulay, Lloyd Gabriel T. Rizada, Jinno Jenkin Sy, Christl Jan S. Tiu, Charlie A. Clarion, and John Carlo B. Reyes. 2020. "Barriers to Online Learning in the Time of COVID-19: A National Survey of Medical Students in the Philippines." MedRxiv 1-19. doi: 10.1101/2020.07.16.20155747.

Bradley, Cynthia Sherraden, Brandon Kyle Johnson, and Kristina Thomas Dreifuerst. 2020. "Debriefing: A Place for Enthusiastic Teaching and Learning at a Distance." Clinical Simulation in Nursing 49:16-18. doi: 10.1016/j.ecns.2020.04.001.

Churiyah, Madziatul, Sholikhan Sholikhan, Filianti Filianti, and Dewi Ayu Sakdiyyah. 2020. "Indonesia Education Readiness Conducting Distance Learning in Covid-19 Pandemic Situation." International Journal of Multicultural and Multireligious Understanding 7(6):491. doi: 10.18415/ijmmu.v7i6.1833.

Costa, Roberto D., Gustavo F. Souza, Ricardo A. M. Valentim, and Thales B. Castro. 2020. "The Theory of Learning Styles Applied to Distance Learning." Cognitive Systems Research 64:134-45. doi: 10.1016/j.cogsys.2020.08.004.

Dellinger, Amy B., Jacquline J. Bobbett, Dianne F. Olivier, and Chad D. Ellett. 2008. "Measuring Teachers' Self-Efficacy Beliefs: Development and Use of the TEBS-Self." Teaching and Teacher Education 24(3):751-66. doi: 10.1016/j.tate.2007.02.010.

Dewaele, Jean-Marc, Andrea Franco Magdalena, and Kazuya Saito. 2019. "The Effect of Perception of Teacher Characteristics on Spanish EFL Learners' Anxiety and Enjoyment." Modern Language Journal 103(2):412-27. doi: 10.1111/modl.12555.

Donnell, Laurie A., and Maribeth Gettinger. 2015. 'Elementary School Teachers' Acceptability of School Reform: Contribution of Belief Congruence, Self-Efficacy, and Professional Development." Teaching and Teacher Education 51:47-57. doi: 10.1016/j.tate.2015.06.003.

Edition, Second. n.d. Coding Manual.

Gegenfurtner, Andreas, Alexander Zitt, and Christian Ebner. 2019. "Evaluating Webinar-Based Training: A Mixed Methods Study of Trainee Reactions toward Digital Web Conferencing." 5-21. doi: 10.1111/ijtd.12167.

Girolami, Gregory S., Julia L. Brumaghim, James G. Priepot, and Jon P. Goveia. 2000. "A Guide to Using SHELXTL.” (January):1-37.

Hasan, Najmul, and Yukun Bao. 2020. "Impact of 'e-Learning Crack-up' Perception on Psychological Distress among College Students during COVID-19 Pandemic: A Mediating Role of "Fear of Academic Year Loss." Children and Youth Services Review 118(August):105355. doi: 10.1016/j.childyouth.2020.105355.

Johnson, Stacy R., Kristy J. Finlon, Roger Kobak, and Carroll E. Izard. 2017. "Promoting 
Student-Teacher Interactions: Exploring a Peer Coaching Model for Teachers in a Preschool Setting." Early Childhood Education Journal 45(4):461-70. doi: 10.1007/s10643-016-0790-1.

König, Johannes, Daniela J. Jäger-Biela, and Nina Glutsch. 2020. “Adapting to Online Teaching during COVID-19 School Closure: Teacher Education and Teacher Competence Effects among Early Career Teachers in Germany." European Journal of Teacher Education 43(4):608-22. doi: 10.1080/02619768.2020.1809650.

Kumar, Ajay. 2015. "Attitude Towards Teaching Profession in Relation to Adjustment among Senior Secondary School Teachers.” International Journal of Science and Research (IJSR) 4(4):830-33.

de la Rama, Jesha May, Matthew Sabases, Abigail F. Antonion, Criselda Ricohermoso, Joel Mayo Torres, Aprillette Devanadera, Cristine Tulio, and Ericson Alieto. 2020. "Virtual Teaching as the 'New Norm': Analyzing Science Teachers' Attitude toward Online Teaching, Technological Competence and Access." SSRN Electronic Journal (July). doi: $10.2139 /$ ssrn.3654236.

Lase, Delipiter. 2019. "EDUCATION AND INDUSTRIAL REVOLUTION 4.0 Delipiter." Jurnal Handayani 10(1):48-62. doi: 10.24114/jh.v10i1.

Lipowsky, Frank, and Daniela Rzejak. 2015. "Key Features of Effective Professional Development Programmes for Teachers." 7(2):27-51.

Mathew, Nalliveettil George. 2019. "No Title." 7(2):100-116.

Moretti, Francesca, Liesbeth van Vliet, Jozien Bensing, Giuseppe Deledda, Mariangela Mazzi, Michela Rimondini, Christa Zimmermann, and Ian Fletcher. 2011. "A Standardized Approach to Qualitative Content Analysis of Focus Group Discussions from Different Countries." Patient Education and Counseling 82(3):420-28. doi: 10.1016/j.pec.2011.01.005.

Myers, J. Mathew, and Regina Halpin. 2002. "Journal of Computing in Teacher Education Teachers'Attitudes and Use of Multimedia Technology in the Classroom." Journal of Computing in Teacher Education 18(4):133-40. doi: 10.1080/10402454.2002.10784449.

Octaberlina, Like Raskova, and Afif Ikhwanul Muslimin. 2020. "Efl Students Perspective towards Online Learning Barriers and Alternatives Using Moodle/Google Classroom during Covid-19 Pandemic." International Journal of Higher Education 9(6):1-9. doi: 10.5430/ijhe.v9n6p1.

Oddone, Kay, Hilary Hughes, and Mandy Lupton. 2019. "Teachers as Connected Professionals: A Model to Support Professional Learning through Personal Learning Networks." International Review of Research in Open and Distance Learning 20(3):102-20. doi: 10.19173/irrodl.v20i4.4082.

Pathak, Anil, and Charatdao Intratat. 2012. "Use of Semi-Structured Interviews to Investigate Teacher Perceptions of Student Collaboration." 8(1):1-10.

Period, Covid-Pandemic, and A. Case Study. 2020. "The Perceptions of Primary School Teachers of Online Learning during the The Perceptions of Primary School Teachers of Online Learning during the COVID-19 Pandemic Period: A Case Study in Indonesia." (July). doi: 10.29333/ejecs/388.

Perry, Nancy E., Lynda Hutchinson, and Carolyn Thauberger. 2008. "Talking about Teaching Self-Regulated Learning: Scaffolding Student Teachers' Development and Use of Practices That Promote Self-Regulated Learning." 47:97-108. doi: 10.1016/j.ijer.2007.11.010.

Perveen, Ayesha. 2016. "Synchronous and Asynchronous E-Language Learning : A Case Study of Virtual Synchronous and Asynchronous E-Language Learning: A Case Study of Virtual University of Pakistan." (March). doi: 10.5944/openpraxis.8.1.212. 
Ponikarovska, Svitlana. 2020. "The Role of Higher School in Personal Becoming." Bulletin of Kharkov National Automobile and Highway University 0(91):216. doi: 10.30977/bul.2219-5548.2020.91.0.216.

Rebaque-rivas, Pablo, and Eva Gil-rodr. 2019. "HCI International 2019 - Posters.” 1034:11522. doi: 10.1007/978-3-030-23525-3.

Reigeluth, Charles M. 2013. "Instructional-Design Theories and Models: A New Paradigm of Instructional Theory." Instructional-Design Theories and Models: A New Paradigm of Instructional Theory 2(January 1999):1-715. doi: 10.4324/9781410603784.

Reimers, Fernando, Andreas Schleicher, Jaime Saavedra, and Saku Tuominen. 2020. "Supporting the Continuation of Teaching and Learning during the COVID-19 Pandemic. Annotated Resources for Online Learning." Oecd 1-38.

Rozitis, Christopher P. 2017. "Instructional Design Competencies for Online High School Teachers Modifying Their Own Courses." TechTrends 61(5):428-37. doi: 10.1007/s11528-017-0204-2.

Tanveer, Afzal Muhammad. 2015. "Teachers Perceptions and Needs towards the Use of ELearning in Teaching of Physics at Secondary Level." (August). doi: 10.12691/education3-8-16.

Taradisa, Nidia., Jarmita, Nida., Emalfida. 2020. "Kendala Yang Dihadapi Guru Mengajar Daring Pada Masa Pandemi COvid 19 MIN 5 Banda Aceh.” UIN Ar-Raniry Banda Aceh $1(1): 23$.

Tularam, Gurudeo, and Patrick Machisella. 2018. "Traditional vs Non-Traditional Teaching and Learning Strategies -- The Case of E-Learning!." International Journal for Mathematics Teaching and Learning 19(1):129-58.

Utecht, Jeff, and Doreen Keller. 2019. "Becoming Relevant Again: Applying Connectivism Learning Theory to Today's Classrooms." Critical Questions in Education 10(2):107-19.

Al Zoubi, Samer. 2018. "The Impact of Exposure to English Language on Language Acquisition." Journal of Applied Linguistics and Language Research 5(4):151-62. 